\title{
The Implications of Interdiction at Sea: for Refugees, Canada and Canadians
}

Clause 8 of Bill C-84 would permit the Minister of Employment and Immigration to make directions with respect to ships entering Canadian waters. This Clause would add new powers to the Immigration Act, 1976 allowing the Minister to forcibly turn away ships from Canada's internal waters, territorial sea or twelve nautical miles off the outer limit of the territorial sea of Canada if $s /$ he believed on reasonable grounds that the ship was bringing one or more passengers to Canada in contravention of the Immigration Act.

There are serious issues that arise out of this Clause. The first issue is whether or not Canada would have jurisdiction in all of the area off the Canadian coast as outlined in the draft legislation. The second issue is whether an act of turning away a ship, thereby potentially returning its passengers to their place of embarkation, would constitute an act of 'refoulement'. The third issue arises out of the silence of this Clause and the Bill, on the question of what information the Minister would use to decide whether s/he had "reasonable grounds" to turn a ship away. This leads to the question of identifying passengers as non-bona fide refugees.

The first issue raised is one of Canadian jurisdiction over its coastal waters. The U.N. Convention of the Law of the Sea, 1982 (UNCLOS) defines four zones moving outward from land: Internal waters, territorial sea, contiguous zone, and high seas. (A/CONF. 62/122) Internal waters consist of ports, harbours, rivers, lakes and canals. Generally, a coastal state can apply and enforce its laws fully against a foreign ship in these waters. The territorial sea extends twelve miles beyond the internal waters. Article 17 of the UNCLOS says the coastal state exercises sovereignty over its territorial sea, subject only to one important limitation: foreign ships must have a right to innocent passage. ${ }^{1}$ Passage is considered 'innocent' so long as it does not prejudice the peace, good order, or security of the coastal State. This means that among other things a coastal State's laws and regulations regarding navigation, health, customs, and immigration must be obeyed by a foreign ship for it to maintain a right to innocent passage. In Article 33 of UNCLOS a third division of the seas proximate to a coastal State is identified.

\author{
Gail E. Misra
}

The contiguous zone is an area adjacent to the territorial sea, extending out a further twelve miles from the territorial sea. A coastal State may exercise much the same control over this zone as in its territorial waters. 2

The high seas are defined by Akehurst as the sea outside a coastal State's jurisdiction. Only international law and the laws of a flag-state (the state whose nationality a ship carries) apply. As Simmonds states, if a ship is attempting, however, to get to the high seas to evade a coastal state "in hot pursuit," the ship is still considered subject to the coastal State's jurisdiction as long as the pursuit began in the coastal State's waters.

The text of Clause 8 of Bill C-84 makes reference to the internal waters, territorial sea, and another twelve miles of sea past the territorial sea. This suggests that Canada has accepted and adopted the concept of a contiguous zone in which it will exercise its jurisdiction. For the purposes of this analysis, this means Canada can oust from its waters any ship that disembarks "any commodity or person contrary to the customs, fiscal, immigxation or sanitary regulations" of Canada. ${ }^{3}$ Such action would not appear to be in and of itself contrary to the principles of international law, as Canada simply would be exercising its sovereignty as authorized by the Law of the Sea. The problems, though, stem from an examination of the requirements of Canadian constitutional law, as well as of international refugee law.

Clause 8 of Bill C-84 is designed to ensure that people who plan to claim refugee status in Canada are not permitted onto Canadian soil if they arrive by ship. If they cannot get to Canada, the Government argues that they will not be in a position to invoke Canadian laws regarding refugee determination, nor protection under the Charter. The Hon. Benoit Bouchard, the Minister of Employment and Immigration, said as much: he does not want to bring ships into Canadian waters "because the Charter of Rights would apply" and the government might be forced to give the passengers a hearing. 4

This position raises several questions. First, how is the Minister to know whether a ship is bringing a person or persons into Canada in contravention of the Immigration Act or Regulations without stopping the ship, boarding it, and assessing each person's claim? Second, if Canada claims sovereignty over its internal waters and territorial sea, then would not the Charter apply as soon as a government official stops a foreign ship in these waters, boards it, and invokes Canadian law? Third, how can Canadian law differ? There is nothing in the Convention of the Law of the Sea that says a State can simply chase a foreign ship out of its waters. In Articles 19, 25 and 111, UNCLOS authorizes a coastal State to respond to infractions of its laws: it may pursue a foreign ship with the intent of stopping and arresting it; but if the coastal State is found to have acted improperly, it may be liable to pay damages. Nowhere is a state permitted to simply chase out a vessel apparently making innocent passage through Canadian waters. Finally, what will constitute 'contravention' of the Act or Regulations such as to bring Clause 8 into operation? Lack of proper travel documents has been said by the Government to be sufficient. Article 31 (1) of the Convention on the Status of Refugees states, however, that a refugee should not be penalized for illegal entry if s/he came directly from the country of persecution. "Coming directly" has been interpreted as "coming in a direct manner without delay" and does not mean that one could not pass through another country en route. 5 The UNHCR has interpreted the term so as not to impose an obligation solely on countries adjacent to countries of persecution. UNHCR accepts that any person who had not de facto residence in an intermediate country should be considered as coming directly from the country of persecution. 6 Thus, persons may not have come with stopover from the country of persecution, but may nonetheless have come "directly." Once in Canadian waters, stopped by a Canadian coast guard or immigration officer, they should therefore be entitled to seek Canada's protection. Michael Schelew, speaking on behalf of Amnesty InternationalCanadian Section, quoted in the Globe and Mail on August 13th, said that Bill C-84 would put "genuine refugees at risk" because their cases would never get heard if the Minister simply turned away ships carrying undocumented refugees.

4

(C) Authors, 1988. This open-access work is licensed under a Creative Commons Attribution-NonCommercial 4.0 International 


\section{Interdiction at Sea ... Cont'd from page 4}

He stated further that Amnesty International was concerned that the criteria for determining whether a ship should be interdicted, instead of just being sent away, was the safety of the vehicle and its passengers. There was no allowance in the Clause for determination of whether or not the passengers were genuine refugees. In a letter to Mr. Jack Ellis, Chairman of the Legislative Committee Bill C-84, Michael Schelew on behalf of Amnesty International reminded the Chairman that the Clause does not require the Minister to ensure that there is another country in which the ship can safely disembark the passengers. These concerns were echoed by such groups as the Inter-Church Committee for Refugees (ICCR), the Canadian Ethnocultural Council, the Canadian Bar AssociationOttawa, and the Toronto Mayor's Committee on Community and Race Relations. These groups also identified other issues arising out of Clause 8. The Canadian Bar Association-Ottawa pointed out that Canada has taken a contradictory position to this clause when it sits on the Executive Committee of the United Nations High Commissioner for Refugees. There Canada recommended that ships carrying refugees should not be turned away from a country and in fact Canada encouraged establishment of a refugee protection process in the South Asian seas when countries in that region were turning away Vietnamese refugees.

Legal experts agree that Clause 8 raises a serious issue of constitutionality. In presentations to the government, Professor James Hathaway, an International Law expert at Osgoode Hall Law School, went so far as to say that not one credible legal expert from outside the Immigration Department has come forward to speak for the constitutionality of the Bill. Professor Marc Gold, also of Osgoode Hall Law School, said simply that "Bill C-84 is unconstitutional" in its present form, and if passed will imperil the lives of many persons seeking refugee status. Gold quoted the Singh decision when saying that persons claiming refugee status are entitled to Charter protections. Madam Justice Wilson, in Singh, said that the Charter would apply to any human being who was physically present in Canada and by virtue of such presence was amenable to Canadian law. This would bring ships in Canadian water into the Charter's ambit. ${ }^{7}$
Barbara Jackman, a Toronto lawyer and expert on immigration law, said that smugglers will take their chances and will attempt to land clandestine arrivals knowing that at worst the ship may be turned away by Canadian coastal vessels. If they are turned away, there are no penalties for the captain or crew, and the captain may set the passengers adrift at sea to be rid of them. ${ }^{8} \mathrm{Mr}$. Bouchard has said that there is no legal obligation for the Canadian government to consider the safety of people who are not in Canadian waters. ${ }^{9}$ Jackman says that for those cast adrift outside Canada's territorial waters the possibilities would be grim, as passing ships would not want to pick up undocumented persons for fear that their passage through Canadian waters would no longer be 'innocent.'

As Jackman points out, Canada has been faced with two boat loads of people, the passengers of which numbered less than 400 . She suggests that the proposed legislation should impose criminal sanctions instead on ship captains who try to smuggle persons into Canada if the legislation is intended to deter. She also recommends that for reasons of safety, the passengers of such ships should be permitted to disembark at a Canadian port and make their claims.

James Hathaway identified in this Clause a major refutation of Canada's international obligations. By turning away persons seeking protection as refugees, he said Canada would be in direct violation of the 'non-refoulement" requirement of the U.N. Convention. He argues that "non-refoulement" is a fundamental obligation under international refugee law, one that "can never be suspended, can never be watered down, can never be overlooked." That obligation, according to Hathaway, includes the obligation to hear the claims of those who arrive at our shores and profess to have been persecuted. Clause 8 , in contrast, would allow the minister, acting alone, to decide that a ship should be forced back into the high seas without anybody on board having an opportunity to be heard. Most experts agree that the best method of dealing with ships clandestinely bringing in persons would be to force the ship into a port, take the passengers off and give them an opportunity to tell their story, and then to charge the captain and crew for violating Canadian laws. This would fulfil all of Canada's obligations, domestic, international, moral, and humanitarian. 10
Gail Misra is a law student at Osgoode Hall Law Scool. The above article was extracted from a law course paper written January 22, 1988 while enrolled in the Intensive Programme in Poverty Law at Parkdale Community Legal Services.

\section{Appendix I: The Implications of Interdiction at Seas}

BILL C-84, An Act to amend the Immigration Act, 1976 and the Criminal Code in consequence thereof

Clause 8

91.1 (1) Where the Minister believes on reasonable grounds that a vehicle within:

(a) the internal waters of Canada,

(b) the territorial sea of Canada, or

(c) twelve nautical miles of the outer limit of the territorial sea of Canada is bringing any person into Canada in contravention of this Act or the regulations, the Minister may, after having due regard to the safety of the vehicle and its. passengers, direct the vehicle to leave or not to enter the internal waters of Canada or the territorial sea of Canada, as the case may be, and any such direction may be enforced by such force as is reasonable in the circumstances.

\section{Appendix II: Convention Relating to the Status of Refugees.}

\section{Signed at Geneva on July 1951}

Article 1, A, (2)

For the purposes of the present Convention, the term "refugee" shall apply to any person who:

Owing to a well-founded fear of being persecuted for reasons of race, religion, nationality, membership of a particular social group or political opinion, is outside the country of his nationality and is unable or, owing to such fear, is unwilling to avail himself of the protection of that country; or who, not having a nationality and being outside the country of his former habitual residence as a result of such events, is unable or, owing to such fear, is unwilling to return to it. IMMIGRATION ACT, 1976

\section{2.(1)}

"Convention refugee" means any person who, by reason of a well-founded fear of persecution for reasons of race, religion, nationality, membership in a particular social group or political opinion,

Cont'd on page 8 
Safe Haven Remedy ... Cont'd from page 3

\section{Precedents for Temporary Refuge in International Law and the Practices of Other Countries}

The proposal to provide temporary refuge to aliens in the United States who cannot safely return to their homelands is supported by principles and norms of international law arising from international agreements and by the practices of other nations.

The United Nations High Commissioner for Refugees has recently declared that individuals fleeing serious danger resulting from conditions of civil strife are protected from forced repatriation by a customary norm of international law that has achieved the status of jus cogens. Furthermore, the High Commissioner identified temporary refuge as being encompassed within the "universally recognized" principle of non-refoulement, which "requires that no person shall be subjected to such measures as rejection at the frontier, or, if he has already entered the territory, expulsion or compulsory return to any country where he might have reason to fear persecution or serious danger resulting from unsettled conditions or civil strife."

Principles of humanitarian law, including the Geneva Convention standards relating to war, argue further in favor of providing temporary protection for foreigners who have fled civil unrest until the danger in their home countries has subsided. Many states have maintained policies of temporary refuge to aliens fleeing internal armed conflict. In 1936, France and Britain provided safe haven to individuals fleeing the Spanish Civil War. In 1956, Austria provided temporary safe haven to over 100,000 individuals who had fled hungary after the unsuccessful October uprising, and again in 1968 to Czechoslovakians fleeing the Soviet invasion and the expected subsequent political oppression. During the Algerian war of independence, several hundred thousand individuals fleeing random violence were granted temporary refuge in Morocco and Tunisia. More recently, Somalia has granted temporary refuge to Ethiopians; the Sudan has provided shelter to both Ethiopians and Chadians; and Pakistan has provided temporary refuge to approximately three million Afghans.
In Canada, a Special Review Committee (SRC), after receiving the applications of refused refugee claimants, may then recommend that an individual who is otherwise deportable be allowed to remain in Canada because of special humanitarian circumstances. SRC guidelines permit consideration of such humanitarian factors as severe oppression in the country of origin, the likelihood that an alien would be severely punished for overstaying his or her visa, and an alien's demonstrated need to live in a democratic system. How this practice will fit into the new procedure (Bill C-55), is not clear.

In Sweden, Denmark and the Netherlands, an alien who is unable to produce sufficient evidence of a well-founded fear of persecution or who has fled conditions of generalized danger is eligible to be a "B" status refugee. Although class B refugees are not refugees under the Convention, they are allowed to remain "on humanitarian grounds because of the political situation in their country of origin, to which (they) could reasonably be expected to return".

The Dutch government has been reluctant to grant class B status to the growing number of Tamils in the Netherlands. However, Tamils who apply for asylum are often allowed to remain in Holland on humanitarian grounds as class " $\mathrm{C}$ " refugees. Class $\mathrm{C}$ status permits the Tamils to work and obtain many benefits. Tamils may be deported however, if another country can be found to accept them, or if it is established that conditions in Sri Lanka have substantially improved.

Germany presently has a policy against returning Afghans, Ethiopians, Iranians, Palestinians from Lebanon and Christian Turks. Germany also gives rejected asylum seekers from Eastern Europe residence permits and work authorizations after one year, but they cannot receive refugee benefits. Non-Eastern European rejected asylum applicants may receive "Duldung" (toleration) permits that allow them to reside in Germany and to work after five years in jobs for which Germans are unavailable.

Spain has allowed asylum status for nonrefugee aliens under a broad category which encompasses those deemed deserving of asylum for humanitarian reasons; in practice, however, asylum for humanitarian reasons has been granted in few cases. More commonly, the reviewing Interministrial Commission recommends that the person be allowed to remain in the country as an alien. This has occurred in the cases of Lebanese, Palestinians from Lebanon, Tamils, Iranians, Iraqans, and Salvadorans. These foreign nationals are entitled only to residence permits and are often unable to obtain work permits.

\section{Conclusion}

A formal temporary safe haven program in the United States would recognize both the humanitarian necessity of protecting those displaced by war and the strictures of the new immigration law. Such a mechanism would have no effect on the protection available under law to refugees, who must prove a wellfounded fear of persecution on an individual basis, and who can ultimately become U.S. citizens. Rather, as in other countries, temporary protection and authority to work would be granted to innocent civilians victimized by war or national disaster.

Arthur C. Helton, lawyer, directs the Political Asylum Project of the Lawyers Committee for Human Rights, New York City.

\section{Seminar Series}

"REFUGEES in POLICY and PRACTICE" is drawing to a close. We wish to thank the Dean of Graduate Studies for co-sponsoring the series again this academic year and for assigning Robert Kreklewich, Doctoral Candidate in Social and Political Thought to assist in the organization of the series during this academic year. We are very grateful to the Masters of several colleges at York University whose donations assisted with the printing of posters and we thank Bobbi Greenberg-Shaefer and staff at York's Communications Department for publicizing the series. We invite the public to the final seminar in the series:

DATE: March 31, 1988:

"Toward a Theory of Refugees and Forced Migration." Professor Anthony H. Richmond and Professor Howard Adelman will present their work on this subject. The seminar will be moderated by Professor Michael Lanphier.

PLACE:

Junior Common Room McLaughlin College (Room 014)

TIME: 2 - 4 p.m. 